\title{
PENYIMPANGAN NILAI-NILAI ETIKA DALAM BERBUSANA ADAT KE PURA DI DESA PENARUNGAN KECAMATAN MENGWI KABUPATEN BADUNG
}

\author{
I Kadek Arista Jaya ${ }^{1}$, Heny Perbowosari ${ }^{2}$, I Gede Sedana Suci ${ }^{3}$ \\ ${ }^{123}$ Universitas Hindu Negeri I Gusti Bagus Sugriwa Denpasar \\ Email: ${ }^{1}$ aristajaya98@gmail.com
}

\begin{abstract}
The development of global currents has an impact on various aspects of life, including community culture. One of them is in terms of clothing which is influenced by foreign cultures. This of course degrades ethical values in the use of clothing, especially clothing used at social events or places of worship such as traditional clothing to temples. The influence of outside culture that is abused certainly causes deviations in ethical values in the use of traditional clothing to the temple, one of the villages affected by the deviation is Penarungan Village. As a tourism destination, the people of Penarungan Village cannot turn a blind eye to outside culture, this causes deviations in ethical values of traditional dress to the temple in Penarungan village. This research uses value theory, behaviorism, and social interaction. The approach used is ethnography. Informants were determined by purposive sampling. The research location chosen was Penarungan Village. Data collection techniques are by observation, interviews, and library techniques. The results of the study show that the forms of deviation from ethical values in traditional attire to the temple in Penarungan Village include: (1) Deviations using kamen, (2) loose hair, (3) transparent and vulgar clothes, (4) T-shirts. the causes of deviations in values. Ethical factors in traditional kepura dress in Penarungan Village include (1) social media, (2) development of the times, (3) economic factors. The strategies of Hindu religious leaders in strengthening ethical values in traditional attire to temples in Penungan Village (1) bring order to the people who violate them, (2) use uniform clothing.
\end{abstract}

Keywords: Deviation; Ethical Values; Traditional Dress to the Temple

\begin{abstract}
Abstrak
Pesatnya perkembangan arus global berdampak pada berbagai segi kehidupan, termasuk pada kebudayaan masyarakat. Salah satunya dari segi berbusana yang semakin terpengaruh oleh budaya-budaya luar. Hal ini tentu saja mendegradasi nilai etika pada pemakaian busana, apalagi busana yang digunakan pada acara kemasyarakatan ataupun ke tempat ibadah seperti busana adat ke pura. Pengaruh budaya luar yang disalahgunakan tentunya menimbulkan sebuah penyimpangan nilai etika pada pemakaian busana adat ke pura, salah satu desa yang terkena dampak penyimpangan yaitu Desa Penarungan. Sebagai destinasi pariwisata masyarakat Desa Penarungan tidak dapat menutup mata pada budaya luar, hal tersebut menyebabkan terjadinya penyimpangan nilai etika berbusana adat ke pura di desa Penarungan. Penelitian ini menggunakan teori nilai, behaviorisme, dan interaksi sosial. Pendekatan yang digunakan etnografi. Informan ditentukan secara purposive sampling. Lokasi penelitian yang di pilih adalah Desa Penarungan. Teknik pengumpulan data yaitu dengan observasi, wawancara, dan teknik kepustakaan. Hasil penelitian menunjukan bentuk-bentuk penyimpangan nilai etika dalam berbusana adat ke pura di Desa Penarungan meliputi : (1) Penyimpangan menggunakan kamen, (2) Rambut terurai, (3) Baju transparan dan vulgar, (4)
\end{abstract}


Baju kaos. Faktor penyebab adanya penyimpangan nilai-nilai etika dalam berbusana adat kepura di Desa Penarungan meliputi (1) media sosial, (2) perkembangan jaman, (3) faktor ekonomi. Strategi tokoh agama Hindu dalam menguatkan nilai-nilai etika dalam berbusana adat ke Pura di desa penarungan (1) menertibkan masyarakat yang melanggar, (2) menggunakan pakaian yang seragam.

\section{Kata Kunci : Penyimpangan; Nilai-Nilai Etika; Berbusana Adat Ke Pura}

\section{Pendahuluan}

Bali sebagai sebuah pulau kecil dan unik memiliki keunikan tersendiri yang menjadikan Bali memiliki daya tarik tersendiri. Oleh karena memiliki banyak keunikan dan keindahan tersendiri, maka Bali sering dijuluki sebagai the last paradise in the world, the island of love, the island of thousand temple. Keindahan ini bukan sekedar julukan, namun sudah dirasakan langsung oleh banyak orang-orang yang datang ke Bali. Bahkan banyak media massa menyebutkan berkali-kali bahwa Bali merupakan salah satu pulau terindah di dunia.

Pesatnya arus budaya global yang secara paksa mendominasi kebudayaan lokal. Hal ini juga memiliki dampak yang sangat signifikan terhadap eksistensi budaya lokal khususnya Bali. Bali yang dikatakan indah, menarik dan menjadi daya tarik para wisatawan dunia kini tidak seindah tampilannya. Budaya Bali yang terkenal mengedepankan etika dan sopan santun, kini mulai berubah kearah budaya hidup mecari kesenangan sebanyak mungkin yang sangat melekat dengan budaya global. Pengaruh pesatnya budaya global menjadi salah satu penyebab rusaknya tatanan nilai-nilai budaya lokal. Hal ini beberapa diantaranya dapat dilihat pada penyimpangan yang terjadi dalam menggenakan busana adat ke pura di masyarakat Bali.

Bila dikaji lebih dalam lagi dalam konteks Weda, tentu terdapat beberapa hal di masyarakat yang menyimpang dari ketentuan dalam Weda. Menyimak makna kitab Bhagawadgita terkait dengan penyimpangan nilai-nilai etika berbusana adat ke Pura tampaknya dapat dikategorikan sebagai berkarakter Rajasika dan Tamasika yang sekaligus mencerminkan Sradha umat akan tercermin dan tingkatan bhaktinya yang ditampilkan secara fisikal-material dalam bentuk ritual-seremonial, lengkap dengan penampilan gaya selebritis, sehingga hal itu dapat dipandang sebagai suatu bentuk sikap atau perilaku yang menjauh dari sentuhan bhatiniah/rohaniah dan kesadaran spiritual, sebagaimana secara ideal dan konsepsual diharapkan agar selalu dilandasi oleh tuntunan etika/kesusilaan dan lebih baik lagi di topang oleh pengetahuan, pemahaman dan penghayatan tattwa.

Mengacu pada kutipan sloka Slokantara, dalam konteks ke Pura, jelaslah bahwa hendak ke Pura, maka sesungguhnya persyaratan yang dituntut cukup sederhana, yang sesuai kaidah etika Hindu. Soal unsur Estetika (keindahan) dalam penampilan memang tidak dihalangi. Setiap manusia memiliki rasa keindahan terhadap sesuatu yang dipandangnya. Nilai keindahan tidak dapat disamakan dengan orang yang satu dengan orang yang lain. Hal ini disebabkan karena nilai keindahan tidak dapat dipaksakan untuk dinikmati, atau dirasakan terlebih tentang seni yang bersifat religious yang dapat memberi dorongan untuk menatap lebih dalam dan lebih jauh.

Jika mengatakan dalam konteks ke Pura, jelaslah harus mengikuti persyaratan yang dituntut yang sesuai kaidah etika Hindu. Namun jika melihat secara langsung di lapangan, masih banyak ditemukan masyarakat yang berbusana menyimpang. Penyimpangan yang dimaksud seperti penggunaan pakaian yang ketat, transparan dan vulgar yang dikenakan oleh kaum perempuan yang rentan merusak konsentrasi para laki-laki saat melihatnya, rambut yang terurai atau sejenisnya yang lebih menekankan pada gaya dan model, kemudian mengesampingkan nilai-nilai etika dan kesopanan. Selain pada perempuan, penyimpangan pada laki-laki biasanya ditemukan ada yang menggunakan pakian baju kaos. 
Pakaian busana ke pura saat ini juga cendrung terlihat mengikuti budaya global yang kering akan makna dan nilai-nilai etika di dalamnya. Pakaian dari budaya global yang ditawarkan penuh dengan nilai-nilai hidup hedomisme atau hanya untuk menikmati kehidupan dimasa kini. Ini jelas berbeda dengan tujuan hidup yang terdapat dalam agama Hindu yaitu moksa yang berarti melepaskan diri dari keterikatan. Disinilah jelas terlihat mengapa etika berbusana harus digaungkan pada masyarakat Hindu Bali pada khususnya agar tidak jauh melenceng diseret arus globalisasi.

Perubahan sosial pada masyarakat Bali bermula dari penerapan pembangunanisme atau suatu politik ekonomi yang mengagungkan pertumpuhan ekonomi sebagai parameter pembangunan pada masa pemerintahan orde baru. Hal ini menciptakan ruang yang subur bagi sistem ekonomi kapitalisme. Bersamaan dengan itu, Bali pun memasuki era globalisasi sehingga perubahan sosial-budaya pada masyarakat Bali meluncur dengan cepat dan memiliki kompleksitas yang amat tinggi. Globalisasi tidak bisa dibendung karena Bali menjadi bagian dari kampung global, bahkan masyarakat Bali akan terus mengalami perubahan yang cepat.

Meminjam gagasan piliang (2004), globalisasi di topang oleh kapitalisme, postmoderisme, dan cyberspace. Kapitalisme merupakan system ekonomi yang berlaku tunggal pada tataran global sehingga dunia mengalami kapitalisme-isasi. Tujuan kapitalisme adalah mendapatkan keuntungan dengan cara menerapkan imperialisme kultural. Dalam rangka mencari keuntungan yang sebanyak-banyaknya, system kapitalisme masukan konsumerisme, hindonisme, materialisne, dan wajahisme atau penampilanisme sehingga melahirkan masyarakat Bali yang menjunjung tinggi "agama pasar".

Desa Penarungan merupakan salah satu desa adat di Bali yang masih terdapat penyimpangan nilai etika dalam berbusana khususnya busana adat ke Pura. Penyimpangan yang dilakukan tentu terindikasi paham ideology kapitalisme, hedonism atau modernism yang dibawa oleh arus globalisai yang tentu saja tidak sesuai dengan budaya local di Bali. Hal ini mnjadi menarik untuk diteliti mengingat masih minimya pemahaman masyarakat mengenai nilai etika dalam berbusana adat ke pura. Berdasarkan hal tersebut, peneliti tertarik untuk melakukan penelitian di desa Penarungan dengan judul peneliian, "Penyimpangan Nilai-Nilai Etika Dalam Berbusana Adat Ke Pura Di Desa Penarungan Kecamatan Mengwi Kabupaten Badung". Penelitian ini akan mengkaji bentuk penyimpangan berbusana dan faktor penyebab penyimpangan tersebut. Penelitian ini juga akan mengkaji setrategi tokoh agama Hindu dalam menertibkan nilai-nilai etika dalam berbusana adat ke pura di Desa Penarungan, sebagai suatu hal yang menarik untuk diteliti.

\section{Metode}

Penelitian ini lebih cenderung menggunakan penelitian kualitatif. Hal ini karena dalam penelitian ini lebih mengarah pada kualitatif yakni untuk menghasilkan data deskritif berupa kata-kata tertulis, lisan dan perilaku orang-orang yang dapat diamati. Penelitian ini dinyatakan dalam bentuk verbal dan dianalisis tanpa menggunakan teknik statistik. Pendekatan dalam penelitian ini menggunakan pendekatan etnografi. Ciri utama pendekatan etnografi adalah berfokus pada pengembangan deskripsi yang kompleks dan lengkap tentang kebudayaan dari kelompok yang berkebudayaan sama. Dalam etnografi, peneliti mencari berbagai pola dari aktivitas yang diekspresikan melalui tindakan mereka yang dapat diamati oleh peneliti. Kelompok berkebudayaan sama tersebut telah lengkap dan berinteraksi dalam waktu yang lama hingga dapat membangun pola kerja yang sama.

Lokasi penelitian ini mengambil tempat di Desa Penarungan, Kecamatan Mengwi, Kabupaten Badung. Pemilihan lokasi ini berdasarkan pertimbangan Desa Penarungan Merupakan daerah wisata, dimana terdapat tempat wisata alam seperti tempat pengelukatan, Tubing Lazy River yang tentunya menjadikan Desa Penarungan sering dikunjungi turis domestik maupun mancanegara yang mengkibatkan adanya pengaruh budaya luar yang masuk 
kesana. Sumber data dari penelitian kualitatif berupa manusia yang disebut informan dan dipilih secara purposive sampling.

Teknik pengumpulan data yang dipergunakan meliputi; observasi, wawancara, studi kepustakaan, dokumentasi. Analisis data memiliki tiga tahapan, yaitu : (1) reduksi data adalah melaksanakan kegiatan mengetik dalam bentuk uraian atau laporan terperinci data lapangan yang didapat selama observasi dan wawancara, (2) display data (penyajian data) adalah mengklarifikasikan secara sistematis data yang didapat sehingga mendapat gambaran keseluruhan dari bagian-bagian tertentu, (3) mengambil kesimpulan adalah data yang bersifat tentatif, diragukan, data diverifikasikan selama tulisan berlangsung, sehingga didapatkan kesimpulan secara utuh, dan menjamin validasi data (Kaelan, 2005).

\section{Hasil dan Pembahasan}

\section{Bentuk Penyimpangan Nilai-Nilai Etika Dalam Berbusana Adat Ke Pura Di Desa Penarungan Kecamatan Mengwi Kabupaten Badung}

Setiap masyarakat pada umumnya memiliki nilai moral tersendiri untuk mengarahkan perilaku masyarakatnya. Desa Adat Penarungan salah satu contohnya juga memiliki nilai norma tersendiri yang telah tertanam di masyarakat. Nilai norma yang berlaku di desa Adat Penarungan tidak saja yang bersifat formal, namun juga yang bersifat non formal. Masyarakat desa adat penarungan juga memiliki norma kesopanan tersendiri. Secara umum norma kesopanan dan norma non formal yang berlaku di masyarakat Desa Adat Penarungan tidak tertulis secara spesifik sebagaimana penjelasan di atas, namun berdasarkan nilai etika.

Norma yang dijelaskan di atas lebih banyak berkaitan dengan norma berbusana adat ke pura. Secara tertulis memang tidak terdapat aturan yang mengatur tentang norma busana adat ke pura, namun masyarakat meyakini dan percaya bahwa ke pura haruslah menggunakan pakaian adat yang sopan. Apabila ada masyarakat yang melanggar, maka dengan tegas petugas pura akan menegur dan bahkan memberikan sanksi sosial berupa dipulangkan atau tidak diijinkan untuk masuk ke pura.

Busana adat ke Pura tentu harus mengandung nilai-nilai etika yang baik agar dapat melakukan pemujaan terhadap Tuhan dengan baik. Penyimpangan-penyimpangan yang terjadi dalam halnya penggunaan busana adat ke Pura perlu kiranya diperhatikan agar tidak berlanjut kedepannya. Dalam penelitian yang peneliti lakukan, bentuk-bentuk penyimpangan penggunaan pakaian adat ke pura ternyata masih ada. Banyak masyarakat yang belum sadar dan bahkan tidak mau tau akan nilai etika dalam sebuah busana adat ke pura. Hal inilah yang menjadi benih penyimpangan penggunaan pakaian adat ke pura yang peneliti temukan di lapangan. Dalam tulisan ini, beberapa bentuk penyimpangan yang peneliti temukan adalah seperti penyimpangan penggunaan kamen yaitu masih ada masyarakat khususnya yang perempuan menggunakan kamen yang melanggar nilai etika dalam bentuk kamen yang lebih bersifat terbuka, selain itu penyimpangan lain adalah masyarakat khususnya yang perempuan masih berbusana adat namun dengan rambut yang terurai. Penyimpangan lain yaitu masih ada masyarakat khususnya yang perempuan menggunakan pakaian busana adat yang bersifat transparan atau brokat dan penyimpangan yang terakhir adalah masih ada masyarakat khususnya yang laki-laki menggunakan pakaian busana adat kaos tanpa kerah. Secara lebih mendalam keempat bentuk penyimpangan yang peneliti temukan akan dibahas secara khusus pada sub bab di bawah ini.

Bentuk-bentuk penyimpangan yang terjadi di masyarakat jika kita bedah dengan teori nilai maka akan ditemukan benang merahnya bahwa penilaian terhadap nilai kerohanian antara manusia yang satu dengan yang lainnya berbeda tergantung dari situasi dan keadaan manusia bersangkutan. Bagi manusia nilai merupakan sesuatu alat untuk memotivasi disegala bidang kehidupan. Hal ini dapat dilihat pada kenyataan manusia yang lain berbuat lain dari nilai-nilai manusia yang lain karena alasan yang lain pula. Jadi nilai sangat berperan sebagai pedoman 
dasar yang menentukan kehidupan manusia dalam interaksinya dengan lingkungan sesuai dengan sifatnya. Teori Nilai, Louis Kettsof menyatakan bahwa nilai itu adalah ajaran-ajaran atau tuntunan kemanusiaan untuk kehidupan manusia dalam interaksinya dengan lingkungan sesuai dengan sifatnya baik bersifat normatif ataupun sosial.

Penyimpangan berbusana adat di Desa Penarungan lebih banyak terjadi dan dilakukan oleh anak-anak muda dengan alasan ingin diperhatikan dan di akui. Hal ini terjadi karena jika berbicara mengenai teori kebutuhan Abraham Maslow bahwa manusia pada dasarnya membutuhkan penerimaan dan cinta dari masyarakat lainnya. Maka hal ini juga terjadi di desa penarungan yaitu masyarakat khususnya anak muda yang perempuan secara tidak langsung sedang memenuhi kebutuhan akan penerimaan dan cinta dari masyarakat dengan menampilkan yang terbaik agar diperhatikan oleh masyarakat.

\section{a. Penyimpangan Penggunaan Kamen}

Kamen dalam busana adat masyarakat Bali adalah kain bahawan yang dipakai untuk menutupi bagian bawah tubuh. Penggunaan kamen tentu sudah memiliki pakem atau nilai etikanya tersendiri, sehingga yang menggunakan nyaman dan yang melihat juga nyaman. Namun dalam tren budaya global seperti sekarang ini yang notabenya lebih mengandung nilainilai barat yang bersifat fulgar, tentu akan sangat bahaya jika diadopsi oleh generasi muda tanpa mampu menyaringnya.

Era globalisasi seperti sekarang ini sangat sulit sekali rasanya untuk dapat membendung dan menyaring nilai-nilai barat yang bersifat eksklusif dan fulgar yang tidak relevan dengan nilai adat ketimuran yang sopan santun. Hal ini terjadi karena saat ini hampir semua masyarakat memiliki media sosial yang mana menjadi gerbang dan wadah menyebarnya budaya global. Lemahnya daya nalar dan sosialisasi atau antisipasi dari pihak yang bersangkutan salah satunya menyebabkan nilai-nilai budaya global dengan sangat mudah diserap dan diterapkan oleh generasi muda saat ini.

Penerapan nilai-nilai barat dari hasil budaya global ada banyak contohnya. Dalam pengamatan dan penelitian yang peneliti lakukan, peneliti menemukan bahwa masyakarat saat ini banyak yang berbusana adat dengan menggunakan pakaian yang mencirikan nilai-nilai budaya barat. Hal ini salah satunya dapat dilihat dari penggunaan kamen dalam busana adat ke pura di desa penarungan. Masyarakat yang datang ke pura beberapa menggunakan kamen dengan sedikit terbuka dan seperti ingin menonjolkan bagian paha. Hal ini tentu sudah termasuk penyimpangan karena berbeda dari norma busana ada yang diterapkan oleh desa penarungan. Penyimpangan ini biasanya lebih rentan dilakukan oleh masyarakat yang notabenya perempuan. Hal ini mengingat bahwa perempuan lebih memperhatikan cara dan tren berpakaian daripada yang laki-laki.

Busana adat ke pura yang menyimpang adalah busana yang mulai keluar dari norma kesopanan. Dalam hal ini maksudnya seperti yang wanita menggunakan kamen jadi yang terlalu ketat, yang agak tinggi dan yang agak terbuka (Wawancara Wijaya Putra, 18 Februari 2021).

Kalau perumpuan biasanya memakai kain santili karena lebih transparan dan tembus pandang terus motifnya juga kadang lebih vulgar dan biasanya pakai lengannya juga pendek di atas siku. Terus kamennya juga di atas mata kaki, terus kadang juga ada yang memakai kamen jadi yang ketat. Biasanya untuk gaya-gayaan gitu rambutnya digerai gak di ikat atau dililit (Wawancara Lucya Dewi, 19 Februari 2021).

Wawancara di atas menunjukan bahwa penyimpangan yang berasal dari penggunaan kamen merupakan salah satu penyimpangan yang dilakukan oleh masyarakat penarungan. Hal ini sebagai mana dijelaskan di atas dilakukan oleh perempuan karena dengan motif mengikuti tren atau jaman. Terlebih penggunaan kamen tidak saja hanya ketat, tapi juga pendek dan terbuka. Hal ini tentu secara etika masyarakat timur tidaklah baik karena dapat mengganggu konsentrasi masyarakat lainnya. 
Nah untuk lansia juga banyak yang menggunakan kamen model sarung. Karena biasanya kan yang digunakan kamen bali isi kancut atau saput (Wawancara Wijaya Putra, 18 Februari 2021).

Penyimpangan kamen selain dilakukan oleh perempuan muda, ternyata menurut Wijaya Putra juga dilakukan oleh lansia. Penyimpanga yang dimaksud seperti menggunakan sarung yang notabenya adalah bukan budaya dan pakem bali. Hal ini tentu berbeda dengan pakem budaya bali seperti menggunakan kamen, saput dan kancut sebagaimana yang disampaikan oleh Wijaya Putra pada wawancara di atas.

\section{b. Rambut Terurai}

Busana adat ke pura merupakan suatu hal yang memiliki nilai etika dan adat kesopanan tersendiri. Busana adat ke pura baik itu untuk laki-laki maupun perempuan biasanya dinilai kesopanannya dari ujung rambut sampai dengan ujung kaki. Dengan kata lain dalam hal ini penataan rambut juga semestinya menjadi hal penting yang harus diperhatikan dalam berbusana adat ke pura karena rambut yang rapi juga mencerminkan penerapan etika dan kesopanan yang baik. Pada dewasa ini, banyak masyarakat yang sedikit mengabaikan pentingnya menata rambut yang rapi saat berbusana adat ke pura. Banyak anak muda khususnya perempuan yang masih mengurai rambutnya. Dalam tradisi dan budaya masyarakat penarungan bahwa rambut yang terurai tentu tidak memiliki nilai etika dan sopan santun.

Bentuk penyimpangan berbusana adat ke pura selanjutnya yang peneliti temukan terjadi di desa penarungan adalah rambut yang terurai. Penyimpangan ini biasanya lebih sering dilakukan oleh perempuan yang motif dibaliknya hanya ingin menunjukan kelebihannya agar diperhatikan oleh masyarakat sekitar. Selain itu mengurai rambut juga sebagai bentuk mengikuti tren yang sedang terjadi di era modern.

Kalau perumpuan biasanya memakai kain santili karena lebih transparan dan tembus pandang terus motifnya juga kadang lebih vulgar dan biasanya pakai lengannya juga pendek di atas siku. Terus kamennya juga di atas mata kaki, terus kadang juga ada yang memakai kamen jadi yang ketat. Biasanya untuk gaya-gayaan gitu rambutnya digerai gak di ikat atau dililit (Wawancara Lucya Dewi, 19 Februari 2021).

Terus dalam baju atau kebayanya biasanya yang lengan agak pendek. Biasanya sih yang digunakan di antara siku terus leher baju agak terbuka dan biasanya rambut yang tidak sopan itu, tidak terikat dan model-model kekinian (Wawancara Wijaya Putra, 18 Februari 2021).

Wawancara di atas dengan sangat jelas menunjukan bahwa masyarakat penarungan masih ada yang mengurai rambutnya atau tidak mengikat rambutnya dengan rapi saat menggunakan pakaian adat ke Pura. Hal ini tentu sebagaimana disampaikan di atas merupakan bentuk penyimpangan yang mesti diperhatikan agar nilai etika dan kesopanan dalam berbusana tidak hanyut oleh perkembangan jaman. Terlebih pura bagi masyarakat Hindu di desa Penarungan merupakan tempat suci yang mesti dijaga kesuciannya baik dari kesucian orang yang datang maupun suci secara sekala dan niskala.

\section{c. Baju Transparan dan Vulgar}

Baju merupakan bagian yang tidak terpisahkan dari sebuah busana. Bahkan baju merupakan utama yang mungkin dilihat oleh kebanyakan orang. Sehingga sangat penting kiranya memperhatikan penggunaan baju agar terlihat indah di mata masyarakat. Baju yang digunakan juga sebaiknya mengandung nilai-nilai etika dan kesopanan yang dianut oleh masyarakat sekitar. Dalam berbusana adat ke pura, baju juga hendaknya rapi, sopan dan bersih. Namun saat peneliti melakukan penelitian di desa penarungan, peneliti menemukan bahwa masih ada sebagian masyarakat khususnya yang perempuan menggunakan pakaian yang sifatnya transparan dan vulgar.

Penyimpangan dalam bentuk pakaian yang transparan dan vulgar juga ditemukan di Desa Penarungan. Pakaian yang transparan ini seperti penggunaan baju yang berbahan kain 
brokat sehingga bisa tembus pandang langsung melihat bentuk tubuhnya, atau bahkan dengan sengaja dibuat ketat sehingga bentuk tubuhnya semakin terlihat. Bagian-bagian tertentu seperti panyudara juga menjadi hal yang kadang ditonjolkan oleh beberapa perempuan entah itu disengaja atau tidak disengaja. Hal ini tentu saja jika berbicara mengenai etika dan kesopanan sudah tentu tidak sesuai.

Pengguanaan kebaya semacam itu tentunya sangat menyimpang dari nilai etika berbusana adat ke Pura yang menonjolkan kesopanan yang utama. Pemakaian kebaya yang transparan juga menyebabkan hilangnya konsentrasi orang-orang sekitar terutama kaum pria.

Kalau menurut saya sebenarnya tergantung pribadi orang yang melihat tapi kalau bisa seorang wanita yang mengenakan busana adat yang terkesan atau agak terbuka itu biasanya sedikit mengganggu. Konsentrasi jadi pecah intinya akan menjadi bahan pembicaraan, terutama pembicaraan orang-orang tua. Ke pura itu kan untuk sembahyang bukan untuk gaya-gayaan. Ini pasti ada hubungannya kaya yang saya bilang tadi yang terbuka, terkesan pasti dia ingin kelihatan beda maka dari itu banyaklah pendapat ini, itu. Agak kurang sopanlah menggunakan pakaian adat yang vulgar. Kalau bisa sih menggunakan pakaian yang memenuhi kriteria norma kesopanan karena ini kan ruang lingkup Pura (Wawancara Wijaya Putra, 18 Februari 2021).

Kalau untuk yang standar ajalah pakai kamen, saput, udeng. Kalau untuk yang wanita sesuai dengan standar. Brokatnya janganlah yang terlalu tembus pandang atau transparan. Intinya jangan sampe memunculkan auratnya. Misalnya susunya sampe kelihatan karena itu bisa merusak konsentrasi (Wawancara Gumatra Astawa, 16 Februari 2021).

Dua wawancara di atas kembali mempertegas apa yang peneliti temukan dilapangan. Masyarakat sendiri juga menilai bahwa pakaian yang digunakan secara transparan dan vulgar itu melenceng dari nilai norma dan kesopanan. Terlebih saat ini berada di wilayah timur yang sangat memegang nilai-nilai kesopanan dan etika. Baju brokat dan isu memunculkan aurat juga membuat beberapa masyarakat sulit untuk konsentrasi. Sehingga ini dengan jelas merupakan bentuk penyimpangan dari berbusana adat ke Pura.

\section{d. Baju Kaos}

Kesopanan menggenakan pakaian tidak saja hanya berlaku bagi perempuan yang notabenya adalah objek yang indah untuk dipandang, tapi juga bagi laki-laki. Pakaian yang sopan bagi laki-laki sebaiknya menggunakan baju ciri khas yaitu sapari atau setidaknya kemeja yang berwarna putih dan bersih. Hal ini karena sesuai dengan norma dan etika yang berlaku secara tersirat di masyarakat khususnya di Bali.

Bentuk penyimpangan berbusana adat ke pura di desa penarungan yang peneliti temukan adalah penggunaan baju bagi laki-laki. Masyarakat yang notabenya laki-laki di desa penarungan masih ada yang menggunakan baju kaos oblong ke Pura. Hal ini tentu terlihat tidak sopan mengingat kaos oblong biasanya digunakan untuk acara-acara gotong royong atau ngayah dan bukan untuk hari-hari suci besar keagamaan. Hal ini disampaikan langsung dalam wawancara di bawah ini.

Terus untuk yang laki-laki biasanya yang digunakan yang sapari yang rapi an agak sopan. Tapi kebanyakan anak muda sekarang masih memakai kain kaos oblong. Apalagi warna putih tetapi banyak sablon isi gambar ini dan itu dan banyak yang menggunakan baju kemeja tapi berbagai motif contohnya motif bunga, daun, dan agak terkesan kurang sopan dan kelihatan seperti mau kundangan (Wawancara Wijaya Putra, 18 Februari 2021).

Pakaian menyimpang untuk laki-laki biasanya pakaian yang digunakan selain sapari. Karena biasanya ada yang memakai kemeja yang bermotif aneh-aneh dan baju kaos (Wawancara Lucya Dewi, 19 Februari 2021). 
Wawancara di atas kembali menegaskan apa yang telah peneliti sampaikan sebelumnya bahwa masyarakat setempat juga menganggap penggunaan kaos oblong itu terkesan kurang sopan jika digunakan ke pura. Baju yang sopan yaitu menggunakan sapari atau kemeja putih yang polos yang tentu sesuai dengan nilai etika dan kesopanan yang berlaku. Sehingga dalam hal ini jelas bahwa penggunaan baju oblong juga termasuk dalam bentuk penyimpangan, namun yang sifatnya masih bisa ditoleransi tergantung dengan kondisi dan situasi.

\section{Faktor Penyebab Adanya Penyimpangan Nilai-Nilai Etika Dalam Berbusana Adat Ke Pura Di Desa Penarungan Kecamatan Mengwi Kabupaten Badung}

Berdasarkan pengamatan yang peneliti lakukan di lapangan, faktor penyebab adanya penyimpangan berbusana adat ke pura secara umum berasal dari 3 hal yaitu media sosial, perilaku tokoh adat dan kurangnya sosialisasi. Hal ini akan lebih dalam dibahas pada sub bab bagian di bawah ini.

\section{a. Media Sosial}

Masyarakat dunia saat ini telah memiliki sahabat yang sangat dekat yang menemaninya kemana-mana bahkan menjadi penghiburnya sehari-hari yaitu smartphone atau ponsel pintar. Ada yang mengatakan bahwa dengan ponsel pintar seserorang seperti menggenggam dunia dengan satu tangan. Dengan kata lain apapun informasi yang kita perlu cari saat ini sudah hampir tersedia sepenuhnya di ponsel pintar. Saat-saat jenuh seseorang juga bisa menggunakan ponsel pintarnya untuk mencari hiburan-hiburan yang sangat beragam dan banyak jumlahnya.

Media sosial adalah salah satu produk dari ponsel pintar yang berisikan begitu banyak informasi baik yang sifatnya positif maupun negatif. Ponsel pintar ibarat pisau yang bisa berguna dengan baik jika mampu mengendalikannya dan tentu bisa menyakiti jika tidak bisa menggunakan. Keberadaan media sosial jika dikaji lebih jauh merupakan bagian dari pemenuhan mesin hasrat dan keinginan. Makanya banyak orang yang memiliki ponsel pintar tidak bisa lepas lama-lama dan mereka mengatakan mengalami kecemasan yang cukup tinggi jika tidak memegang ponsel pintar. Hal ini dengan kata lain bisa disimpulkan bahwa hasrat dan keinginan serta kebutuhan akan cinta dan penerimaan benar-benar diperhatikan oleh pembuat ponsel pintar sehingga banyak orang sulit untuk lepas darinya.

Penggunaan media sosial merupakan gerbang masuknya budaya global dan nilai-nilai barat yang vulgar dan penuh ekspresif yang tentu sangat berbeda dengan nilai-nilai timur yang sopan dan beretika. Banyak generasi muda tanpa menyaring informasi kemudian menerimanya begitu saja dan bahkan menerapkannya hingga menjadi kebiasaan. Hal ini tentu berbahaya mengingat jati diri bangsa yang penuh kesopanan akan runtuh dan jika runtuh kita akan mudah diserang oleh budaya luar. Hal inilah yang terjadi juga di masyarakat Penarungan khususnya terkait dengan penggunaan busana adat ke Pura.

Faktor yang memiliki peran penting adanya penyimpangan di Desa Penarungan adalah media sosial. Banyak masyarakat melihat hal-hal yang menarik di media sosial sehingga menimbulkan rasa ingin untuk mencoba karena begitu menarik baginya. Namun sangat disayangkan tren yang sedang terjadi di media sosial dibawa ke ranah agama yaitu ke pura dalam bentuk berbusana dengan menggunakan pakaian yang vulgar, transparan atau yang tidak sesuai dengan norma dan etika adat sekitar.

Faktor media sosial tentu saja itu sangat mendukung sama kayak saya bilang tadi karena dia merasa mampu, otomatis dia itu akan melihat di instagram atau facebook. Artinya dia mulai mengikuti bagaimana tren terkini lalu dikombinasikan dibawa ke acara-acara di rumah misalnya baju apa yang tren kebayanya dimodif-modif pakai itu agar terkesan beda, mengikuti jaman. Pasti dah dia itu melihat di instagram di facebook, dia mengikuti gaya-gaya dan tren artis yang kekinian. Sangat mendukung menurut saya faktor media sosial. (Wawancara Wijaya Putra, 18 Februari 2021) 
Wawancara di atas menunjukan dengan jelas bahwa faktor media sosial sangat menentukan terjadinya penyimpangan berbusana adat ke pura khususnya dari instagram dan facebook. Tentu faktor ini menjadi faktor yang sulit untuk dicegah karena sudah menjadi bagian hidup sehari-hari masyarakat setempat. Banyak anak muda juga mengikuti tren dengan dimodifikasi agar terkesan menarik dan kekinian.

\section{b. Perkembangan Jaman}

Era globalisasi saat ini secara tidak langsung telah membentuk identitas budaya global yang berlaku di seluruh dunia. Masyarakat secara tidak langsung juga dibentuk untuk memiliki satu budaya. Sehingga saat ini banyak yang kita temukan terjadinya kepunahan budaya dan tradisi di berbagai belahan dunia. Manusia dipaksa untuk mengikuti perkembangan jaman yang didesain semakin kompleks dan penuh kompetitif dan secara tidak langsung menggusur budaya dan tradisi budaya masyarakat setempat.

Budaya tentu syarat akan nilai-nilai tertentu yang terkandung di dalamnya sehingga mampu meneruskan dari generasi ke generasi selanjutnya. Namun saat ini dengan adanya perkembangan jaman dan era globalisasi masyarakat lebih terbentuk oleh budaya-budaya luar yang didapatkannya misalnya dari ponsel pintar dan secara perlahan mulai tidak mempelajari budaya setempat. Hal ini tentu sangat berbahaya karena budaya merupakan fondasi suatu bangsa.

Bentuk penyimpangan berbusana adat di desa penarungan juga salah satunya didukung kuat oleh perkembangan jaman. Masyarakat mengikuti budaya-budaya luar dan tanpa sadar mengabaikan budaya sendiri yang penuh dengan nilai etika dan kesopanan. Masyarakat yang mengikuti tren tanpa menyaring tentu masuk dalam kateogi menyimpang sebagaimana yang telah dibahas panjang lebar di bagian atas.

Utamanya di standar kebaya seperti modis atau model, dimodifikasi sesuai dengan jamannya yang terkini dan itu terkadang tidak pas dengan situasi dan kondisi. Seperti brokat tembus pandang dan transparan (Wawancara Gumatra Astawa,16 Februari 2021).

Faktor yang mendukung itu biasanya mengikuti tren atau jaman yang modern. Terkadang orang melihat modelnya ini bagus dan menarik, tapi secara etika kurang bagus juga. Karena kalau kepura biar khusuk kita sembahyangnya. Dari orang yang memakai tidak bener dan Dari segi modelnya juga sensitif pada mata yang melihat. Jadinya konsentrasinya tidak fokus dan jadi buyar (Wawancara Gumatra Astawa,16 Februari 2021).

Di era globalisasi yang berkembang media sosialnya, jadi mereka bisa meniru gayagaya misalnya melihat di instagram kaya motif-motif baju yang menurutnya menarik supaya bisa terlihat lebih cantik atau ganteng dan bisa menarik perhatian orang lian gitu. Jadi dia sampe lupa atau seenaknya aja biar dia tetap terlihat cantik (Wawancara Lucya Dewi, 19 Februari 2021).

Wawancara ketiganya di atas dengan sangat jelas sekali menunjukan bahwa memang benar pengaruh perkembangan jaman dan globalisasi merupakan faktor penyebab yang dominan yang menyebabkan terjadinya penyimpangan berbusana adat ke pura di desa Penarungan. Masyarakat sekitar yang peduli menilai bahwa model dan tren yang diikuti terkadang tidak bagus dan kurang beretika sehingga kadang mengganggu kenyamanan orang untuk datang ke Pura.

\section{c. Faktor Ekonomi}

Faktor yang mendukung terjadinya penyimpangan di Desa Penarungan yang peneliti temukan di lapangan salah satunya adalah faktor ekonomi. Hal ini karena orang-orang dalam kategori ekonomi yang cukup mampu biasanya membeli model-model pakaian busana adat ke Pura yang mengikuti tren perkembangan. Hal ini juga didukung oleh banyaknya took-toko 
pakaian adat yang mendesain pakaianya agar sesuai dengan tren dan mempromosikannya dengan sangat baik sehingga banyak masyarakat yang tertarik untuk membelinya.

Kesehatan ekonomi inilah yang mendorong mereka untuk menggunakan pakaianpakaian yang mengikuti tren. Jika dikaji lebih dalam, sebenarnya tidak ada yang salah dengan mengikuti tren dan perkembangan jaman. Karena memang sebagai individu dituntut untuk mengikuti tren dan perkembangan jaman agar tidak tertinggal jauh. Namun yang menjadi permasalahan adalah mengikuti tren kemudian mulai menghilangkan nilai-nilai etika dan kesopanan yang telah dipegang dengan baik di masyarakat.

Menurut saya kebanyakan dari faktor ekonomi, karena mungkin ia merasa ekonominya agak tinggi maka dari itu iya mulai menggunakan gaya kekinian, menirukan gaya artis, berpakaian agak terbuka untuk menarik perhatian dan agar dilihat bahwa dirinya itu berbeda dari yang lain. Contoh seperti ibu-ibu atau cewek yang merasa ekonominya agak mampu mulai menggunakan kebaya mahal, desainnya yang kayak model dan terlalu ketat, rambutnya yang direbonding dan biasanya terurai dibiarkan begitu saja. Seperti tadi biar kelihatan agak berbeda dengan yang lain (Wawancara Wijaya Putra, 18 Februari 2021).

Wawancara di atas kembali lagi menegaskan bahwa memang faktor ekonomi menjadi salah satu faktor penting yang menyebabkan terjadinya penyimpangan berbusana adat di Desa Penarungan. Dengan ekonomi yang mapan tentu ia bisa lebih leluasa dalam membeli suatu barang untuk menghias tubuhnya agar terlihat menarik oleh masyarakat walaupun tanpa disadari ternyata menyimpang dari nilai-nilai etika dan kesopanan.

\section{Strategi Tokoh Agama Hindu dalam Menguatkan Nilai-Nilai Etika dalam Berbusana Adat ke Pura di Desa Penarungan Kecamatan Mengwi Kabupaten Badung.}

Berdasarkan teori interaksi sosial di atas maka sangat penting kiranya dalam menerapkan strategi tokoh adat mampu menjalin interaksi dengan baik dengan masyarakat. Dalam hubungannya dengan berbusana adat ke Pura, peneliti mengamati bahwa tokoh adat desa penarungan juga memiliki strategi dan juga melakukan interaksi dengan masyarakatnya. Hal ini dapat dilihat dari strategi yang digunakan untuk menguatkan nilai-nilai etika yaitu dengan menertibkan masyarakat yang melanggar dengan memberitahu untuk menggunakan pakaian yang lebih sopan dan juga dengan strategi membuat pakaian yang seragam dengan menyelipkan dan tentu berlandaskan nilai-nilai etika yang telah disepakati oleh masyarakat Desa Penarungan.

\section{a. Menertibkan Masyarakat yang Melanggar}

Penyimpangan yang terjadi dalam halnya penggunaan pakaian adat ke pura tentu mendapatkan perhatian yang cukup serius oleh Desa Penarungan. Hal ini tentu harus dilakukan untuk menghindari agar masyarakat tidak terus-menerus berbapakaian busana yang menyimpang. Selain itu perhatian serius dari desa Penarungan juga harus dikuatkan dalam strategi-strategi yang digunakan agar apa yang dilakukan bisa tepat sasaran dan bukan justru ikut menyimpang dalam halnya penertiban.

Salah satu strategi yang dilakukan dalam menangani penyimpangan yang terjadi dimasyarakat adalah dengan menertibkan dan memberikan sanksi kepada masyarakat yang melanggar. Dalam hal aturan yang mengatur secara jelas untuk penerapan sanksi memang tidak ada yang tertulis, namun aturan ini bersifat tersirat dan kesepakan bersama karena sesuai etika dan norma kesopanan.

Berbusana itu kan terkait nilai etika, jadi konsepnya memang aturan yang tidak tertulis dan sanksinya pun sanksi moral, sanksi sosial. Jadi kalau untuk tertulis biasanya ada sanksi hukumnya berupa material. Tapi kalau diaranah susila itu sanksinya pasti berupa sanksi sosial. Jadi moralitas itu sebenarnya tidak bisa diukur (Wawancara Jro Mangku Nanda Acarya, 20 Februari 2021). 
Aturan diawig-awig tidak ada, tapi secara umum masyarakat kalau sudah kepura nganggen pakaian putih atau kuning. Tidak ada pernah mengumumkan bahwa ke pura harus pakai baju seperti ini, tapi masyarakat sudah paham dengan sendirinya pakaian yang seperti apa yang harus digunakan (Wawancara I Made Widiada, 20 Februari 2021).

Wawancara di atas menyatakan bahwa terkait dengan busana itu lebih masuk dalam hal terkait dengan etika yang sanksinya pun adalah sanksi yang bersifat sosial atau moral. Karena sebagaimana yang disampaikan di atas, aturan secara tertulis dalam awig-awig tentu tidak ada namun ini kembali menuntut kesadaran masyarakat dalam halnya menggunakan pakian yang sopan dan sesuai etika. Masyarakat yang melanggar dalam hal ini biasanya ditegur dan tidak diperbolehkan untuk masuk ke pura dan mempersilakan pulang untuk mengganti pakaian agar lebih sopan.

Kalau sudah ke pura, sudah pasti ini ranah suci. Perilaku harus suci, busana harus suci karena sudah aturan baju, kamen, saput, itu biasanya putih atau kuning. Nah kalau kebiasaan disini aturan kalau orang tidak memakai pakaian putih diingatkan oleh pecalang. Pakaian harus bersih atau suci (Wawancara I Made Widiada, 20 Februari 2021).

Kalau ada orang yang menggunakan pakaian brokat atau transparan dan lengan bajunya pendek, maka pasti akan di tegur. Kalau ada yang berpakaian lengan pendek, harus pulang. Ini juga baru aturan seperti ini karena baju model baru dan lain sebagainya. Ini tidak boleh. Memang tidak ada sanksi tapi orang melihat itu tidak bagus. Biar tidak kelihatan seperti model yang merangsang (Wawancara I Made Widiada, 20 Februari 2021).

Wawancara di atas sangat menegaskan bahwa bentuk-bentuk pakaian yang menyimpang yang dilakukan oleh masyarakat saat ke pura tentu akan diberikan sanksi yaitu dengan dipulangkannya ke rumah. Hal ini tentu bertujuan untuk menjaga kenyamanan masyarakat yang datang ke pura agar tetap konsentrasi pada tujuan awalnya yaitu untuk mendekatkan diri kehadapan Tuhan.

\section{b. Menggunakan Pakaian yang Seragam}

Strategi yang digunakan untuk mencegah penyimpangan yang terjadi selanjutnya yaitu dengan menyeragamkan penggunaan busana adat ke pura khususnya bagi yang perempuan. Hal ini tentu dapat mencegah adanya penyimpangan-penyimpangan seperti kain yang trasnparan atau vulgar. Dengan digunakannya pakaian busana adat ke pura yang seragam khususnya untuk perempuan yang tergabung dalam ibu-ibu PKK, setidaknya dapat mencegah penyimpangan yang terjadi.

Dengan penggunaan pakaian yang seragam masyarakat juga merasakan keserasian dan kekompakan yang tentu dapat menambah nilai kekeluargaan dan rasa memiliki satu sama lain. Hal ini tentu dapat dicontoh juga oleh desa-desa lain yang juga terjadi banyak penyimpanganpenyimpangan busana adat ke pura. Dengan penggunaan pakaian yang seragam terbukti untuk perempuan yang tergabung dalam PKK tetap menjaga nilai-nilai kesopanan dan etika sebagaimana budaya dan adat masyarakat ketimuran.

\section{Kesimpulan}

Busana adat ke Pura tentu harus mengandung nilai-nilai etika yang baik agar dapat melakukan pemujaan terhadap Tuhan dengan baik. Bentuk-bentuk Penyimpanganpenyimpangan yang terjadi dalam halnya penggunaan busana adat ke Pura adalah seperti penyimpangan penggunaan kamen yaitu masih ada masyarakat khususnya yang perempuan menggunakan kamen yang melanggar nilai etika dalam bentuk kamen yang lebih bersifat terbuka, selain itu penyimpangan lain adalah masyarakat khususnya yang perempuan masih 
berbusana adat namun dengan rambut yang terurai. Penyimpangan lain yaitu masih ada masyarakat khususnya yang perempuan menggunakan pakaian busana adat yang bersifat transparan atau brokat dan penyimpangan yang terakhir adalah masih ada masyarakat khususnya yang laki-laki menggunakan pakaian busana adat kaos tanpa kerah. Faktor penyebab adanya penyimpangan yang peneliti amati di desa penarungan, masyarakat yang berpakaian menyimpang karena melalui proses interaksi baik dengan teman sebaya atau dengan tren yang sedang marak di media sosial. Masyarakat yang berbusana menyimpang ternyata juga mendapatkan banyak sekali stimulus utamanya dari sahabat kecil yang menemaninya kemana-mana yaitu smartphone atau media sosial. Berdasarkan pengamatan yang peneliti lakukan di lapangan, faktor pendukung terjadinya penyimpangan berbusana adat ke pura secara umum berasal dari 3 hal yaitu media sosial, perilaku tokoh adat dan kurangnya sosialisasi. Tokoh adat desa penarungan juga memiliki strategi dan juga melakukan interaksi dengan masyarakatnya. Hal ini dapat dilihat dari strategi yang digunakan untuk menguatkan nilai-nilai etika yaitu dengan menertibkan masyarakat yang melanggar dengan memberitahu untuk menggunakan pakaian yang lebih sopan dan juga dengan strategi membuat pakaian yang seragam dan tentu berlandaskan nilai-nilai etika yang telah disepakati oleh masyarakat Desa Penarungan.

\section{Daftar Pustaka}

Agung, Anak Ayu Ketut. 2000 Busana Adat Bali.Denpasar : Palawa Sari

Aristadewi, Desak Putu, 2010. Eksistensi Ngusabha Petung sebagai media Pendidikan Nonformal bagi Masyarakat di Desa Muncan Kecamatan Selat Kabubaten Karangasem ( Perspektif Pendidikan Agama Hindu)

Bagus, Lorens. 2005. Kamus Filsafat. Jakarta PT. Gramedia Pustaka Utama

Creswell, J. W., 2014. Penelitian Kualitatif \& Desain Riset Memilih di Antara Lima Pendekatan. Yogyakarta: Pustaka Pelajar

Horton, Paul B., dan Chester L. Hunt. Sosiologi Jilid 1.(Jakarta: Erlangga, 1996), hal. 56

Hikmawati, Fenti. 2012. Bimbingan Konseling. PT Raja Grafindo Persada

Hasan, Iqbal. 2002. Meteologi Penelitian dan Aplikasinya. Jakarta : Ghalia Indonesia

Iqbal, Hasan. 2002. Pokok-Pokok Materi Penelitian dan Aplikasinya. Jakarta : Ghalia Indonesia

Kaelan. 2005. Metode Penelitian Kualitatif Bidang Filafat. Yogyakarta : Paradigma

Koentjaraningrat. 1979. Metode-Metode Penelitian Masyarakat. Jakarta: Gramedia

Mark K. Smith. 2009. Teori Pembelajaran dan Pengajaran. Yogyakarta : Mirsa Media Pustaka

Moleong, B. J. 2004. Metodologi Penelitian Kualitatif. Bandung. Remaja Karya

Pudja, G. 1981. Bhagawadgita (Pancama Weda). Jakarta: Nayasari

Redana, Made. 2006. Panduan Praktis Penulisan Karya Ilmiah Dan Proposal Riset. IHDN Denpasar

Sudarminta, J. 2013. Etika Umum Kajian tentang Beberapa Masalah Pokok dan Teori Etika Normatif. Yogyakarta: Kanisius

Sagala, H. Syaiful. 2013. Etika Dan Moralitas Pendidikan. Jakarta: Kencana

Sugiyono. 2013. Metode Penelitian Pendidikan : Pendekatan Kuantitatif, Kualitatif, Dan $R \& D$. Bandung : Alfabeta

Spradley, James P. 2017. Metode Etnografi. 2 ed. (Amri Marzali, Pentj) Yogyakarta: Tiara Wacana

Sugiyono. 2012. Metode Penelitian Kuantitatif. Bandung: Alfabeta

Sugiyono. 2005. Memahami Penelitian Kualitatif. Bandung: Alfabeta

Soekanto, Soerjono. 2005. Pokok-Pokok Sosiologi Hukum. Jakarta: Raja Grafindo Persada.

Santoso, Singgih. 2010. Statistik Parametrik, Konsep dan Aplikasi dengan SPSS. Cetakan Pertama, PT Elex Media Kompitundo, Jakarta: PT Gramedia. 
Semiawan, Conny. R.2001. Belajar dan Pembelajaran Taraf Usia Dini. Jakarta : PT Ikrar Mandiri Abadi

Tim Penyusun. 1990. Kamus Besar Bahasa Indonesia. Jakarta : Balai Pustaka

Widana, I Gusti Ketut, 2011 Menyoroti Etika Umat Hindu Ke Pura Berpenampilan Selebritis. Denpasar: Pustaka Bali Post

Walgito, Bimo. 2003. Pengantar Psikologi Umum. Yogyakarta: Andi.

Zuriah Nurul. 2005. Metodologi Penelitian Sosial dan Pendidikan. Jakarta : PT Bumi Aksara 